\title{
REMÉDIO DA LEITURA EM TERRA SONÂMBULA
}

\section{Remedio de la lectura en Tierra sonámbula}

AnA CATARINA COIMBRA DE MATOS

Centro de Língua Portuguesa - Camões I.P. / Universidad Autónoma de Madrid

acmatos@camoes.mne.pt

ORCID.org/0000-0001-9066-9610

Recibido/Received: septiembre 2021; Aceptado/Accepted: octubre 2021

Cómo citar/To cite this article: Coimbra de Matos, Ana Catarina, "Remédio da leitura em Terra sonâmbula", Revista de Estudios Africanos, 2, (2021): páginas 24-37.

DOI: https://doi.org/10.15366/reauam2021.2.002

Resumo: Numa terra em tempo de guerra, cheia de misérias e dor, uma criança descobre uma esperança, a leitura. Muidinga encontrará nos Cadernos, que lê à luz de uma fogueira, a ausência do medo noturno, uma fonte de sonho através das tantas e tantas histórias e, no fim, a sua identidade perdida. A leitura é a fuga da dura realidade do fim das aldeias, a fuga da condena à solidão, pois abre a porta à imaginação que inunda a realidade da criança sem memória. A leitura em voz alta para o seu único companheiro, Tuahir, permite a partilha de histórias, seguindo uma tradição oral ancestral. O sonho da leitura transpõe-se para a realidade mediante a brincadeira de infância de fingir serem personagens e também pela revelação final da identidade das histórias, assim, o irreal dilui-se no real.

Palavras-chave: Muidinga, leitura, histórias, sonho, brincadeira.

Resumen: En una tierra en tiempos de guerra, llena de miseria y dolor, un niño descubre una esperanza, la lectura. Muidinga encontrará en los Cuadernos, que lee a la luz de una hoguera, la ausencia del miedo nocturno, una fuente de ensueño a través de las muchísimas historias y, al final, su identidad perdida. La lectura es un escape a la cruda realidad del fin de los pueblos, la huida de la condena a la soledad, ya que abre la puerta a la imaginación que inunda la realidad del niño sin memoria. La lectura en voz alta a su único compañero, Tuahir, permite el compartir historias, siguiendo una antigua tradición oral. El sueño de la lectura se transpone a la realidad mediante el juego infantil de fingir ser personajes y también a través de la revelación final de la identidad de las historias, de esta manera lo irreal se diluye en lo real.

Palabras clave: Muidinga, lectura, historias, sueño, juego.

\begin{abstract}
In a land in war, full of misery and pain, a child discovers a hope, reading. Muidinga will find in the Notebooks that he reads by the light of a bonfire the absence of night fear. He will find a dream source through all the stories and also right at the end his lost identity. Reading is a way of escaping from the harsh reality of the end of the villages, escaping from being condemned to loneliness, because reading opens the door to imagination that takes over the reality of the child with no memory. Reading aloud to his only companion, Tuahir, allows him to share stories, following an ancient oral tradition. The dream of reading is transposed to reality through the childhood game of pretending to be characters and also through the final revelation of the identity of the stories; thus, the unreal is diluted into the real.
\end{abstract}

Key words: Muidinga, reading, stories, dream, game.

Ler é sonhar pela mão de outrem.

Fernando Pessoa 


\section{INTRODUÇÃO}

Mia Couto publica o seu romance Terra Sonâmbula em 2008, um romance que visa a terra moçambicana em guerra, sentindo o medo, a segmentação e a desesperança num período póscolonial, em que a sociedade multicultural mostra signos evidentes da época colonial, mas também das culturas tradicionais.

Com presença portuguesa desde o século XV, a "ocupação colonial não foi pacífica. Os moçambicanos impuseram sempre lutas de resistência (...) Na prática a chamada pacificação de Moçambique pelos portugueses só se deu já no séc. XX" (Portal do Governo). Moçambique tornase independente a 25 de junho de 1975 após a queda da ditadura salazarista em Portugal. Contudo, a sua independência não traz a paz e, em 1977, inicia-se uma guerra civil de violência extrema num país fragmentado, marcado pela segmentação, classificação e hierarquização nas culuras tradicionais (Pereira, 2016: 356). Esta guerra durará 15 anos:

Em 1992 assinaram um tratado de paz que punha formalmente termo à guerra; estabelecia-se um prazo para a desmobilização das tropas e planos para eleições multi-partidárias sob a supervisão das Nações Unidas. A força de paz da ONU foi colocada no terreno e, com ajuda internacional, pôs-se em marcha um programa de repatriação e reestabelecimento dos refugiados (Porto Editora).

O romance de Mia Couto decorre no contexto da guerra civil, narrando uma terra sem paz e dividida, com comunidades e famílias destruídas, e retratando a diversidade cultural e racial através de um hibridismo evidente, que será transposto para a escrita mesmo a nível linguístico. O escritor brincará com a palavra, transformando-a e criando-a à medida daquilo que quer transmitir com inovações linguísticas de hibridização que surpreendem o leitor com um tom que retorna à infância. Serão subtítulos deste artigo algumas dessas palavras como sozinhidão, brincriação ou pensageiro, revelando a intenção do seu romance com dois planos narrativos alternados: o da situação presente do dia-a-dia e o da situação presente da leitura noturna, que ganha protagonismo com a revelação da memória de outrém e de uma identidade esquecida. Mia Couto escolhe uma criança mestiça para protagonista da história, revelando o hibridismo na raça da moçambicanidade. É um miúdo chamado Muidinga cuja sozinhidão, fruto da guerra, vence com o seu companheiro, o velho Tuahir, através da brincriação, da brincadeira de criar outra realidade, como pensageiro, ou seja, passageiro da viagem pela leitura que discorre no seu pensamento, veículo que faz despoletar uma (ir)realidade.

Muidinga representa um "eu" moçambicano órfão não só de pais, mas de identidade, de raízes, de comunidade, de pátria, numa situação em que a vida só continua na imaginação e nos sonhos. A vida para em tempo de guerra, a "estrada está morta", “A estrada não traz ninguém”, só há mudanças na paisagem (Couto, 2013: 64). Os jovens têm sonhos e esperança, querem encontrar uma saída, partir. Os adultos resignam-se, preferem o refúgio, esperar, a segurança de uma vida em que nada muda. A criança anseia pela vida, ir à descoberta pelos matos e deixar um autocarro seguro, porque morto, está queimado e já não cumpre a sua função. Deseja uma família, por isso, chama tio a Tuhair mesmo sem ligação de sangue. Necessita uma aldeia, atando um cabrito que encontra, em vez de o matar para saciar a sua fome, pois sente que o animal lhe dá o conforto de um sentimento de comunidade: "Ihe dá um sentimento de estar em aldeia [...] o sentimento de família humana" (Couto, 2013: 37).

Na narrativa de Mia Couto, são vários os pontos de vista oferecidos através da grande variedade de personagens: o africano e o europeu, o moçambicano e o português, o colonizado e o colonizador, o jovem e o idoso, a mulher e o homem, o feiticeiro e o padre, o vivente e o defunto. A obra reflete a visão da moçambicanidade, a qual reside nesta combinação da diversidade cultural e racial numa identidade multicultural (Coimbra de Matos, 2021: 136). Não obstante, são uns olhos infantis que irão guiar o leitor. Mia Couto consegue transmitir o tom infantil, inocente e esperançado do seu protagonista, "atribui às vozes do universo tradicional (...) as cores dos sonhos infantis" (Cantarela, 2012: 153), mesmo quando a situação narrada é dramática, paira a leveza da 
infância inocente, da fantasia, do sonho. Na tradição cristã, a criança é "el más grande en el reino de los cielos" (La Biblia, Mt 18, 4), pela inocência, a falta de maldade da sua vida na terra. Muidinga, como uma personagem-tipo que representa a infância, é o símbolo dessa inocência. Neste artigo, a análise deter-se-á nesta personagem Muidinga, um olhar mais inocente e de esperança que é, essencialmente, fruto da falta de memória, mais do que da idade, criando uma verdadeira infância, cheia de sonhos em terras africanas. No entanto, a "ausência de memória do personagem é a metáfora da perda forçada dos mistérios que cercam o povo" (Costa e Godoy, 2018: 7) que se devem recuperar para a reconstrução da identidade. Será através da leitura que a criança (re)construirá a identidade individual e coletiva.

Em Mia Couto, trata-se a questão da realidade e da fantasia, essa fina fronteira, impalpável, híbrida que confunde o leitor, imbuído entre a modernidade e o ancestral, entre a realidade europeia e a africana, duas culturas que colidem e abrem espaço ao debate da distinção daquilo que é real, a partir de uma perspetiva individual encaixilhada em vivências pessoais. $\mathrm{O}$ horizonte de expectativas do leitor é diferente consoante o mundo que conhece e as experiências que viveu. Assim sendo, a classificação da literatura de Mia Couto não é unânime e cada cultura marca um entendimento diverso da obra. Discute-se o realismo da obra, ora realismo mágico, ora fantástico, ora maravilhoso, ora animista. A visão africana inclina-se mais para a animista, o qual "presents us with a form of religiosity that is not explicitly tied to an expressed doctrine, a codified set of beliefs, or an elaborated theology. It may be seen, very broadly and fundamentally, as providing avenues for knowing our way around our world and society" (Garuba, 2003: 283). Paradiso defende o termo realismo animista para definir a estética da literatura africana, pois visa $o$ "reanimar" de uma cultura que se espelha na escrita:

só o animismo explica o mundo africano, onde o mundo 'natural' convive com o 'sobrenatural', sendo ambas as realidades para o africano, porém, uma visível e a outra não [...] Talvez, quando Couto diz que o "fantástico" está presente no mundo africano, não se utiliza do termo no sentido literário, mas sim, quimérico, que para a cultura branca, cristã e ocidental, não existe na realidade material; o fantástico do africano é uma realidade, só que não visível aos nossos olhos eurocidentais (Paradiso: 2015, 277).

A realidade visível e invisível, natural e sobrenatural, o mundo dos vivos e dos mortos convivem na literatura de Mia Couto, compondo a realidade moçambicana. Logo, em Terra Sonâmbula, o mundo do sonho tornar-se-á real.

\section{TERRA DE MISÉRIAS}

Numa terra de misérias, terra em ruínas, terra enlouquecida pela guerra em que as balas são as sementes da destruição, há uma interrogação: "Será que a terra, ela sozinha, deambula em errâncias?" (Couto, 2013: 101).

\subsection{Sozinhidão}

Muidinga deambulará pelos arredores do autocarro, enfrentando-se à história de Siqueleto e de Nhamataca, dois homens assaltados pela loucura devido à luta contra o mal da sozinhidão. Ambos acabam por morrer representando a impossibilidade do fim da sozinhidão. Um quer que as aldeias sobrevivam com a sua comunidade e o outro quer curar as feridas do passado, que as pessoas se unam e sonhem.

Siqueleto fala uma língua local que a criança desconhece, mas que Tuahir entende, servindo de mediador entre a tradição ancestral e a criança. $O$ homem não suporta que a aldeia fique deserta, por isso, quer caçar pessoas para as semear e que nasçam mais. Muidinga e Tuahir caem numa armadilha, uma enormíssima cova, mas são salvos pela escrita, a criança escreve o nome de Siqueleto numa árvore, criando-se uma árvore que dará Siqueletos. Assim, o homem sente que já pode morrer, porém, "com ele todas as aldeias morriam. Os antepassados ficavam órfãos da terra, os vivos deixavam de ter lugar para eternizar as tradições" (Couto, 2013: 86). A sua morte representa o 


\section{Remédio da leitura em Terra sonâmbula}

fim das tradições ancestrais, das línguas locais, de um lugar que os mortos possam visitar, o fim da vida em comunidade.

Depois, encontram o fazedor de rios, um conhecido de Tuahir do tempo colonial em que trabalhavam juntos. Nhamataca quer fazer um rio, porque o "rio limparia a terra, cariciando suas feridas" (Couto, 2013: 88), eliminaria as marcas dolorosas da guerra como uma mãe e uniria as pessoas, formar-se-iam famílias, que voltariam a sonhar, a ter esperança, a ter futuro: "nenhum rio separa, antes costura os destinos dos viventes [...] Talvez (...) traga de volta o sonho àquela terra mal amada" (Couto, 2013: 89). A morte de Nhamataca simboliza a morte do sonho. Para a criança, "Morreu um homem que sonhava, a terra está triste como uma viúva" (Couto, 2013: 91). Tuahir age como intermediário novamente, desta vez, entre o passado colonial e a criança.

A solidão - sozinhidão - e a tristeza, deixada pela guerra, é demasiado dura para o homem e todos procuram o conforto da comunidade. $\mathrm{O}$ homem tem uma grande necessidade de se sentir parte de um todo. Segundo as Sagradas Escrituras, o homem tem de viver em comunidade, pois forma parte de um conjunto, como um órgão é parte de um corpo:

Pues todos nosotros, judíos y griegos, esclavos y libres, hemos sido bautizados en un solo Espíritu. Porque el cuerpo no se compone de un solo miembro, sino muchos. Aunque el pie dijera: "Como yo no soy mano, no pertenezco al cuerpo", no por eso dejaría de pertenecer al cuerpo. (...) Si el cuerpo entero fuera ojo, ¿dónde quedaría el oído? (...) Si todos fueran un solo miembro, ¿dónde quedaría el cuerpo?” (La Biblia 1 Cor 12, 13-15 17 19).

A guerra destrói o país, desfaz as famílias, separa as pessoas: "a guerra rasgou os cantos da terra" (Couto, 2013: 159). O homem sente-se só. Resta-lhe a terra enlouquecida em que há covas para os mortos, para os vivos ou para os moribundos. Contudo, sozinhar-se não é a natureza humana: "Já me fartava daquela sozinhidão" (Couto, 2013: 97). Muidinga queixa-se ao velho Tuahir, homem que o salvara de uma cova destinada a enterrá-lo vivo e a quem chama tio por querer colmatar o sentimento de solidão, por necessitar criar laços de sangue mesmo que imaginários:

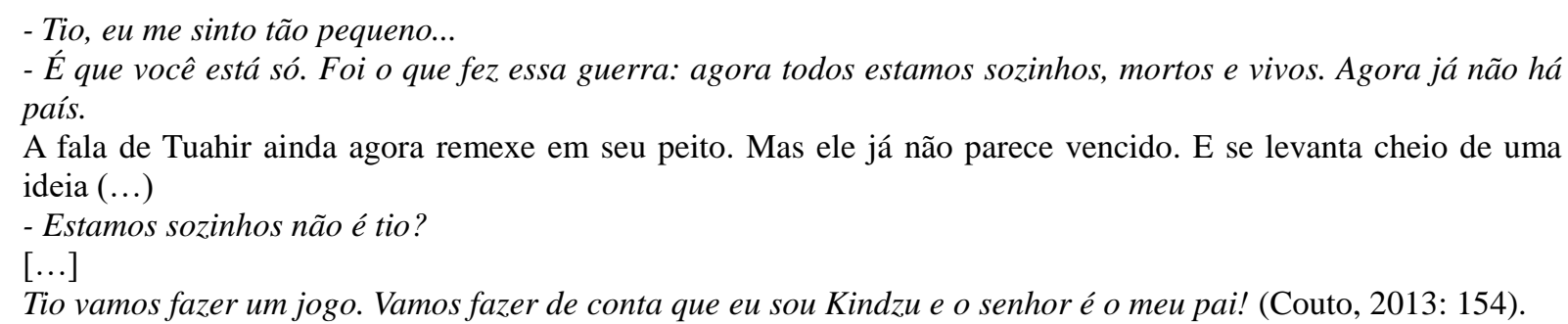

\subsection{Estórias}

Muidinga lê histórias nos Cadernos de Kindzu que revelam memórias dolorosas de várias personagens, por isso, para alguns, a bebida é um bálsamo que os ajuda a esquecer o passado, uma dor que só pode desaparecer com a perda de memória. A realidade é demasiado dura, mas Muidinga não a sabe, é resguardado pela falta de memória. As personagens são assaltadas pela tristeza profunda que surge nos desesperançados adultos, ou mesmo nas crianças. Por exemplo, Kindzu queria "ser naparama, vingador das tristezas da minha gente" (Couto, 2013: 33). Mais crescido, entende que os adultos se embebedam para esquecer os terrores vividos: "- Precisamos esquecer quase tudo, não é? Agora, eu entendo bem os babalazes de meu pai. / - Preciso esquecer muitomuito" (Couto, 2013: 111). O seu velho amigo Surendra ficou "clausurado em tristeza" (Couto, 2013: 117) e Kindzu acaba por deixar Surendra e Assane "entregues à tristeza" (Couto, 2013: 122). Quanto às mulheres que encontra, "queria conhecer a (...) tristeza" (Couto, 2013: 119) de Carolinda, esposa do administrador; do rosto da prostituta Juliana "se desprendiam gotas de grossa tristeza, ensopando o pó de arroz" (Couto, 2013: 135); e tia Euzinha ao saber que Farida vive "Seus olhos se 
inundam de tristeza" (Couto, 2013: 183). A tristeza espalha-se também pelas crianças. Kindzu reconhece os olhos do irmão pela tristeza que encontra neles: "Aqueles olhos eram de uma tristeza que eu já conhecera [...] Me rebateu um remorso fundo [...] aqueles olhos se mostraram humanos, capazes de lágrimas" (Couto, 2013: 118). Mas era no campo de refugiados onde residia a maior tristeza humana: "era coisa de pasmar a tristeza" (Couto, 2013: 183).

Nessas memórias escritas, surgem personagens que ajudarão Muidinga a re(construir) a sua identidade, a criar uma nova memória. Apesar de ser a história de Kindzu desde a independência do país, em que parte da sua aldeia para ser um naparama, guerreiro de justiça, até à sua morte no final do romance, as histórias destes Cadernos estão intrínsecamente ligadas à vida de Farida, cujas últimas linhas revelam ser a mãe da criança que almeja saber a sua identidade. Kindzu encontra Farida num barco encalhado, espiritado, enfeitiçado, onde chega levado por um tchói, que significa um anão fantasma. Ela pede-lhe para contar a sua história, o único remédio para melhorar o seu estado. Farida, condenada desde o seu nascimento, pois é filha do Céu, começa a desfiar as suas dolorosas lembranças:

Cumpria um castigo ditado pelos milénios: era filha-gémea, tinha nascido de uma morte. Na crença da sua gente, nascimento de gémeos é sinal de desgraça [...] sua irmã morreu. Deixaram-na morrer com fome. Fizeram isso por bondade: para aliviar a maldição. Enterram a menina no pequeno bosque sagrado onde dormem as crianças falecidas [...] Foi semeada [...] A mãe de Farida nunca mais teve filhos. Dizem que ela não foi capaz de apagar a sua impureza após o nascimento. Fizeram as cerimónias: não resultou. Queimaram a palhota, juntaram todas suas coisas numa grande fogueira.

A mãe ficou ali, sofrendo culpas por ter subido ao Céu, único lugar em que se pode encontrar meninos gémeos. Chorou então o que ela não pode chorar no enterro da filha. A tradição ordena: ninguém chore em luto, o lamento não pode senão chamar mais desgraça. Para Farida a morte da irmã não foi nunca mencionada: tua irmã? Ficou na casa da avó, ficou lá viver. Assim se murmurava (Couto, 2013: 71-72).

Ao ser obrigada a matar uma das filhas gémeas à fome, a dor que a mãe sente é enorme e não há cerimónia que alivie tal sofrimento. Depois do enterro, não deve chorar para não aumentar desgraças, a sua casa é queimada e tem de abandonar a aldeia com a outra gémea sobrevivente para viverem isoladas, sem visitas, pelo medo do contágio, assim, são condenadas à sozinhidão. Além disso, o lugar onde moram enche-se de fome e morte por se quebrar a tradição, pois a mãe, na realidade, apenas finge matar a filha e entrega-a a um viajante que não conseguia ter filhos.

Mais tarde, cruelmente, a mãe morre afogada na lama numa cerimónia mágica para pedir chuva, momento doloroso em que Farida fica órfã em criança:

meteram a velha num buraco e foram-no enchendo de água. Ela pedia: me deixem, tenho frio.

Mas as mulheres não abrandavam [...] visitara o Céu e se ela estivesse molhada, certamente as nuvens também se encharcariam. As chuvas viriam, por fim.

- Parem, ela está sofrer, gritou Farida.

Mas elas prosseguiram, cobrindo a coitada com água fria. Até que se afastaram dançando e cantando, deixando a mãe no fundo da terra ensopada. Farida se aproximou, quis ajudá-la a sair. Mas ela recusou: devia (...) matoparse, pagar sua dívida com o mundo. Toda a noite a filha permaneceu na cabeceira do buraco. E lhe cantou um embalo, fosse a mãe a pequenina, saída do ventre da jovem. Cansada, Farida adormeceu. [...]

Desde então, a infância de Farida ficou órfã. Ela cresceu, acarinhada por si mesma, na infinita espera da sua mãe. Acreditava que ela regressaria, envolta em seus tristes trapos (Couto, 2013: 73-74).

Farida, uma criança deixada sozinha no mundo, sobrevive graças à crença, à ilusão, de que a mãe regressaria. Sonhava com a mãe, que vinha com um pote como aquele que se teria enterrado a irmã. Depois de a irem buscar, mais uma vez para um ritual da chuva, decide partir daquela terra onde está condenada à sozinhidão.

É adotada por um casal português, Virgínia e Romão Pinto, e é educada como uma portuguesa ao se tornar filha de colonos. Por um lado, Virgínia fez "nascer a outra raça que agora nela existia" (Couto, 2013: 75) e trata-a como uma verdadeira filha. Por outro lado, Romão olhava para ela como mulher e não como filha, o que a levava a sentir "uma mistura de nojo e receio". 


\section{Remédio da leitura em Terra sonâmbula}

Nunca sentiu a casa destes portugueses com um lar apesar do carinho daquela segunda mãe que também acaba por deixá-la, pois teme não ter forças para poder tratar da menina. Virgínia acaba por entregá-la à Missão onde começa a segunda orfandade de Farida, sofrendo o abandono novamente. Porém, a menina sente falta da quentura onde nascera e decide abandonar a Missão e regressar à aldeia da mãe onde ainda tem uma tia. No caminho, visita Virgínia para matar a saudade, mas é Romão que encontra em casa, homem que, aproveitando a oportunidade de estar a sós com ela, a viola à noite quando ela já está deitada no seu quarto:

Os passos dele cercavam-lhe o medo (...) Em silêncio, rezou com desespero. Colocou tanta fé nesse socorro que perdeu o receio do que pudesse suceder (...) Quando seus dedos roçaram o rostro da menina ele sentiu o molhado de caladas lágrimas. Essa tristeza ainda mais lhe afiou os apetites. (...) envolvendo Farida (...) a doidecendo (...) ela se pequeninava. Lá fora, a meiguice da lua não fazia suspeitar quanto ódio se fermentava naquele quarto. Os anjos se demoravam (...) Na aflição ela se perguntava: e afinal Deus? Por que se demora tanto? [...] Memórias antigas da raça lhe avisaram: melhor seria ela se deixar, sem menção nem intenção. $\mathrm{O}$ português se homenzarrou, abusando dela toda inteira [...] adormeceu (...) Empurrou o peso daquele corpo como quem afasta uma culpa.

Amanhecia (...) saiu (...) Chorou, chorou. Queria atar a tristeza com o fio de suas lágrimas. Chamou todo o ódio contra aquele homem que a violara. Mas o ódio não veio. A culpa era só dela, transitando entre esses mundos (Couto, 2013: 79-80).

A menina, dividida entre as duas cultura, a africana de origem e a portuguesa de adoção, procura a proteção de Deus que não chega e a memória da sua raça, do povo colonizado, aconselha à submissão para seu bem. No fim, desesperada, triste, doida, cheia de ódio, sozinha e sem saída, submete-se à vontade do português e é violada. E, mais do que ódio para soltar, o que sente é, apenas, a culpa.

De regresso à sua aldeia com a tia Euzinha, tem a terrível certeza de que está grávida daquele homem branco que a violou e, consequentemente, o menino seria mulato. Por esta razão, torna a ser condenada à sozinhidão, não podendo confessar a verdadeira raça do menino, nem mentir dizendo que era albino. Tendo nascido gémea, seria afastada como "a pior das leprosas, condenada para sempre à solidão" (Couto, 2013: 80). Finalmente, quando a criança nasce, Farida não se sente mãe, nem sequer deseja cuidar do bebé, o menino sobrava-lhe e vai entregar esse lapso da vida à igreja. Mais tarde, tenta recuperar esse menino, desolado e sem sorriso, que vive na Missão: Gaspar. Tenta renascer como mãe, porém, ele foge depois de saber que a mãe o quer ver e Farida não volta a saber dele. Sem lugar em terra para viver, uma terra que a condena, permanece sozinha no barco onde foi deixada por pescadores e aceita esta situação aliviada como se de uma prenda do destino se tratasse. Confessa que é "um espírito que vagueia em desordem por não saber a exacta fronteira que nos separa de vocês, os viventes" (Couto, 2013: 84) e pede a Kindzu que procure o seu filho, pois é a última âncora para partir e abandonar a sua terra. mas pensa que era preferível que estivesse morto, pois "na morte se está melhor" (Couto, 2013: 100) do que naquela terra.

Kindzu parte em busca de Gaspar, encontra Virgínia e fica a saber do seu encontro com o menino. Gaspar é salvo por ela de ser enterrado vivo, porque as crianças querem ouvir a história dele antes de o enterrarem e, nesse momento, Virgínia descobre que ele é Gaspar, filho do seu falecido marido, decidindo já não o enterrar, mas ele foge novamente. Quanto a Romão, pai de Gaspar, acorda morto no seu caixão dez anos depois da sua morte e pergunta por Farida, mas não menciona Gaspar. Apesar de falecido, ainda anda a aprender a ser morto (Couto, 2013: 146), por esse motivo, é visto por Virgínia e Kindzu quando conversam no casarão onde o casal português vivia com Farida. Mais tarde, Kindzu encontra tia Euzinha, mas Gaspar tinha sido transferido para outro centro de deslocados. No campo, descobre que conheceu a irmã gémea de Farida através da tia, quem descreve a relação de mães e filhos naquela guerra pela sobrevivência: "Fiquei a saber que havia mães que roubavam a comida dos filhos e, no meio da noite, lhes tiravam a manta que os 
protegia do frio [...] Simplesmente (...) ensinavam aos filhos os modos de sobrevivência" (Couto, 2013: 185).

No fim, Farida não esperou que Kindzu regressasse com Gaspar, pois nunca o encontraria numa terra imensa em que a guerra era ainda maior e morre numa explosão no farol da esperança, que ficava perto do barco. A tristeza e o cansaço de Kindzu fazem-no querer desexistir e regressar à sua aldeia, livre do peso das terríveis lembranças que despeja no papel: "escritas estas lembranças ficam presas no papel, bem longe de mim" (Couto, 2013: 200). A memória é demasiado pesada para ser guardada e deseja esquecer os horrores vividos. Kindzu termina os Cadernos contando o seu último sonho, em que encontra Gaspar com os seus Cadernos e, quando o chama, é “como se nascesse por segunda vez" (Couto, 2013: 204). Por conseguinte, revela-se a verdadeira identidade de Muidinga, que seria Gaspar na outra vida que não recorda. Uma memória demasiado pesada para ser guardada por uma criança, mas necessária para saber quem é afinal. Uma criança não desejada, fruto de uma violação, abandonada pela mãe, ignorada pelo pai, quase enterrada por duas vezes, mas sempre salva, com a memória apagada, tem uma nova oportunidade para viver na brincriação, um mundo de imaginação e sonho.

O romance termina com as folhas dos Cadernos de Kindzu a voar e todos os "escritos se vão transformando em páginas da terra" (Couto, 2013: 204), porque as histórias são sonhos para quem as lê, são um descanso da realidade, e a terra é uma costureira de sonhos.

\subsection{Memória}

Mia Couto apaga a memória de uma personagem de modo a que, por um lado, haja um laivo de esperança nesta Terra de Misérias, onde a memória implica dor e, por outro lado, para que a memória (individual e coletiva) possa ser (re)construída. A personagem de Muidinga isento da dor da memória desperta apenas inocência e sonhos de uma infância de esperança. Simultaneamente, essa falta de memória inquieta-o por se traduzir na ausência da sua identidade. Por conseguinte, a personagem mais velha que o acompanha, evitando que fosse enterrado, dá-lhe uma segunda vida que preenche com as fantasias da imaginação fértil da infância.

Deste modo, Tuahir e Muidinga fogem ao sofrimento através da brincadeira, do fingimento. Fingem ser personagens desses Cadernos de histórias, como Kindzu e o pai. Tuahir brinca a limpar o machimbombo como a antiga estação de comboios onde trabalhava para dar esperança à criança (Couto, 2013: 140), inclusive finge pôr adubo na terra como se estivesse semeada e o alimento fosse nascer da mesma. Tuahir facilita a infância de Muidinga, permite que ele seja criança. Fingindo ser seu familiar, dá-lhe uma nova família. Permitindo que não mate o animal e o ate, dá-lhe uma nova aldeia. Albergando-se no autocarro, dá-lhe uma nova casa. Varrendo o autocarro, dá-lhe uma nova esperança. Viajando sempre perto do autocarro, dá-lhe uma nova terra segura, estável e protegida. Contando uma história a Siqueleto, dá-lhe um sonho: "Tuahir se revela, por um instante, como um curandeiro amenizando o universo, seu paciente" (Couto, 2013: 68).

Apesar da vontade de Tuahir de que a criança crie uma nova identidade, Muidinga não esquece que há um passado desconhecido que lhe pertence e vai indagando numa tentativa de o recuperar:

- Você ainda continua com essa mania de encontrar seus pais? Está proibido! Ouviste? Não quero lhe ver pensando nesse assunto. Nunca mais.

(...) se controla (...) empurra o banco onde o miúdo permanece sentado.

- Olha lhe vou dizer uma coisa: seus pais faleceram. Sim, eles foram mortos com balas de bandidos. É por causa disso eu sempre estou insistir: abandona essa merda de ideia.

Vira costas. Muidinga parece impassível, sua alma desenhada só em diagonal. Era como se já soubesse, tudo aquilo não constituísse novidade nenhuma. Ou quem sabe não acreditasse na verdade da revelação. Ali ficou, estagnado [...] silencioso (...) contrariado" (Couto, 2013: 51).

Tuahir desconhece o passado da criança e, talvez, para o sossegar diz que os pais 


\section{Remédio da leitura em Terra sonâmbula}

morreram, talvez que intuísse uma história infeliz e o quisesse proteger de sofrer mais. No entanto, Muidinga insiste em saber a verdade sobre as suas raízes, os seus antepassados, a sua identidade, sem perder a esperança, e acaba por encontrá-la no sonho da leitura. Para Muidinga, ler é sonhar pela mão de Kindzu e sonhar torna-se na descoberta inesperada da sua identidade: Gaspar. Passado e presente unem-se pela leitura de um sonho premonitório de Kindzu.

Os Cadernos revelam que a personagem Muidinga, também tem um nome português: Gaspar. Cada nome representa uma etapa da sua vida, as quais vão sendo reveladas em paralelo ao longo da narrativa, pois a leitura dos Cadernos de Kindzu é intercalada com a narrativa do momento presente que se vai desenrolando até ao fim. Estes dois nomes também marcam os seus diferentes antepassados, representando a união dos opostos, a reconciliação da origem africana com a portuguesa, a união da raça negra e da branca, exigindo uma espécie de pacificação do passado moçambicano, mesmo se doloroso, como a época colonial. É uma personagem mulata, filho de um português branco e uma moçambicana negra, que o abandona na Missão aos cuidados de padres e freiras portugueses que o ensinam a ler e falar português, desconhecendo, assim, as línguas locais. Posteriormente, "adotado" por um falso tio que o levou a um feiticeiro, sofre os efeitos da feitiçaria com a perda da memória. Vive fugido da guerra com este falso parente moçambicano, que é extrabalhador da estação de comboios da época colonial, o qual também fala a língua local para além do português e não sabe ler, levando a criança a adoptar a posição do mais velho, como contador de histórias para a transmissão do conhecimento, durante a leitura em voz alta. Conhece muitas das crenças e tradições moçambicanas pela convivência com Tuahir e através das histórias que ouve e que lê:

A leitura dos cadernos de Kindzu pela criança permite-lhe reconstituir uma memória que não é memória recente mas sim memória primordial. A incorporação do imaginário tradicional mergulha as personagens num passado anterior ao passado recente, um passado mítico de dimensão poética, filosófica e espiritual, que faz desta narrativa uma viagem iniciática em que, pouco a pouco, Muidinga vai redescobrindo as suas raízes, reconstruindo uma identidade que poderia ser qualificada de 'moçambicanidade' (Levécot, 2011: 141).

Nos Cadernos de Kindzu é narrada uma memória coletiva da moçambicanidade. Existe a memória primordial que vem dos antepassados, como distingue Levécot, transmitida pela tradição oral que encontramos nas crenças e tradições de um povo africano. Esta memória é transmitida a Muidinga pela leitura e pela convivência com Tuahir e une-se à memória mais recente das lembranças coletivas e individuais de cada personagem dos Cadernos. Se, por um lado, se apaga a memória da criança no plano narrativo do dia-a-dia, por outro lado, recupera-se a sua identidade no plano noturno da leitura, a qual, no fundo, simboliza a moçambicanidade.

A recuperação da memória faz-se a partir de uma memória emprestada, a memória de um jovem atormentado pelo medo, o que mostra o sofrimento de todas as crianças mergulhadas na guerra. Kindzu e a terra eram atormentados por não respeitarem os antepassados, o presente e o passado têm de estar em harmonia, senão os mortos aparecem para pôr ordem: "Respeitar a tradição, honrar os mortos é, assim, o caminho assegurado para viver em harmonia com os antepassados-deuses, de que os mortos são os intermediários" (Ferreira, 2007: 422). O desconhecimento pela falta de memória e pela tenra idade de Muidinga exime-o da culpa e torna-o inocente, não sendo atormentado por nada do passado, nem pelos espíritos dos seus antepassados mortos, nem pelas sombras, nem pelos sonhos como acontece ao herói da sua história, Kindzu. O medo não o domina, surge apenas com o escuro da noite quando tem de dormir como a qualquer outra criança. O contrário ocorre com o jovem Kindzu em que o medo está presente desde que pensa em contrariar as crenças dos seus antepassados, pois deseja sair da sua aldeia para se juntar aos naparamas: "Sacudi a ideia, tocado pelo medo" (Couto, 2013: 29). Posteriormente, iniciado o abandono da terra "Minha única posse era o medo" (Couto, 2013: 104). Kindzu procura um urgente esconderijo da gente desordeira: "uma pistola e disparou [...] Mais tiros [...] escorreguei (...) cabeça enfiada no chão. Cheirava a mijo (...) uma latrina. Eu estava encharcado era de medo, nem 
me lembrei do nojo. Permaneci ali, rezando para que aquela guerra não chegasse às traseiras" (Couto, 2013: 121). Nos sonhos, é seu pai morto que o atormenta por ter deixado a aldeia, pacificando-se com ele quando descobre que isso serviu para ensinar os outros a sonhar. As histórias são sonhos e Kindzu oferece-os com a escrita da sua viagem. Memória e sonho confundem-se e Kindzu torna-se um sonhador de lembranças quando escreve.

Muidinga combate o seu único medo com a leitura, a qual lhe oferece a vivência do sonho através do mundo imagético do seu herói, Kindzu, que vai conhecendo à medida que avança na leitura. Acaba por descobrir que este chega a arriscar a sua própria vida e a atrasar os seus planos de ser um naparama para o encontrar e uni-lo com a sua mãe, as suas origens. Este herói, involuntariamente, é o grande revelador do passado da criança, imprescindível para (re)construir a sua identidade e, apesar de não ter conseguido levar Gaspar à mãe, guia-o às suas origens.

\section{REMÉDIO DA LEITURA}

A leitura é o motor da esperança numa terra desesperançada, com uma única estrada, morta, pois "a guerra tinha morto a estrada" (Couto, 2013: 9); num caminho circular, onde se vagueia sem destino, pois "Pelos caminhos só as hienas se arrastavam" (Couto, 2013: 9); e uma paisagem que se "mestiçara de tristezas nunca vistas" (Couto, 2013: 9), pois a "guerra contaminara toda a sua terra" (Couto, 2013: 9) e "os viventes se acostumaram ao chão, em resignada aprendizagem da morte" (Couto, 2013: 9). Este é o ponto de partida para Muidinga e o velho Tuahir, que o acompanha, desesperançados "Vão para lá de nenhuma parte [...] Vão na ilusão de, mais além, haver um refúgio tranquilo" (Couto, 2013: 9), uma ilusão que conduz à sobrevivência, que não deixa desistir da vida, entrando num mundo de fingimento paralelo à realidade, numa brincriação em que um autocarro queimado, não os podendo levar para outra terra, cumprirá a função de casa. Uma vez destruído pelo fogo, já não poderá tornar a arder, logo, é um refúgio seguro.

Na Bíblia, o fogo é um dos elementos que simboliza o Espírito Santo, tendo uma ação purificadora pelo seu poder transformador: "te he refinado como plata, te he probado en el crisol de la tribulación" (La Biblia, Is 48, 10). Portanto, o fogo purifica e regenera (https://www.dicionariodesimbolos.com.br/fogo/). Assim, depois da tribulação sofrida pelo incêndio, o autocarro é refinado, purificado, e renasce das cinzas como um refúgio para a esperança renovada das personagens. Lá, encontrarão a ilusão nos Cadernos, na leitura de histórias, momento que depende do fogo, existente na fogueira que Muidinga precisa para poder ler de noite. $\mathrm{O}$ fogo ilumina as páginas e ilumina as personagens com a ilusão que renova a sua esperança, assim como o fogo santo iluminou os apóstolos: "Se les aparecieron unas lenguas como de fuego que se repartieron y se posaron sobre cada uno de ellos; quedaron todos llenos del Espíritu Santo y se pusieron a hablar en otras lenguas, según el Espíritu les concedía expresarse" (La Biblia, Hch 2, 1 4). Mediante o fogo da fogueira que acompanha a leitura, Muidinga passa a falar na língua da ilusão, do imaginário, do sonho. Por conseguinte, ler é sonhar: "Nesse panorama desolador, sonhar é buscar refúgio para o sofrimento, é buscar esperança onde não há pistas que levem a ela, é ter a coragem de ousar buscar caminhos para suportar o tormento que parece não ter fim" (Oliveira, 2009: 105). Assim, a leitura funciona como um mecanismo de libertação da situação presente de guerra em que vivem: "A literatura assume um status salvador para esse 'miúdo' moçambicano, numa conjuntura de "dependência", porém com uma sensação de liberdade" (Duarte e Job, 2014: $6)$.

Muidinga procura soluções à tristeza e à solidão através da brincadeira com a imaginação derivada da leitura e não aceita a tristeza e a desesperança do seu companheiro de viagem:

...já perdi a esperança.

- Mentira. Se tivesse perdido por que razão me havia de oferecer esse apito?

$\mathrm{O}$ velho pede então que o miúdo dê voz aos cadernos. Dividissem aquele encanto como sempre repartiram a comida. Ainda bem você sabe ler, comenta o velho. Não fossem as leituras eles estariam condenados à solidão. 


\section{Remédio da leitura em Terra sonâmbula}

Seus devaneios caminhavam agora pelas letrinhas daqueles escritos (Couto, 2013: 139-140).

A leitura é o que os alimenta, fá-los sair da realidade para entrar no mundo da imaginação, do sonho, apaziguando o sofrimento da solidão, da falta de comunidade, pois o homem deve viver em comunidade, todos formam um todo, um povo, um país.

\subsection{Pensangeiro}

Muidinga faz tudo menos render-se "queria uma vez mais partir, tentar descobrir nem sabia o quê, uma réstia de esperança, uma saída daquele cerco" (Couto, 2013: 64), mas as viagens que mais gozo lhe dão são as noturnas, as imaginárias pelas páginas que lê. Barthes afirma que se chama escritor "não àquele que exprime o seu pensamento, a sua paixão ou a sua imaginação por frases, mas sim àquele que pensa frases: um Pensa-Frase (isto é: aquele que não é nem um pensador nem um fraseador)" (Barthes, 2001: 96). O escritor pensa e escreve frases em simultâneo, surgem frases no pensamento à medida que escreve, as frases do processo de criação. Mia Couto, no seu processo de brincriação através do seu hibridismo lexical, chama ao leitor: "pensangeiro", aquele que não é um pensador, nem um passageiro, mas sim aquele que pensa e viaja no seu imaginário concomitantemente, viaja em pensamento à medida que lê, o passageiro da leitura que vivifica a sua imaginação e fecunda o seu sonho. Muidinga é passageiro de uma viagem fantástica, provocada pelo sonho da leitura. Ao viver num autocarro, também é um passageiro simbolicamente, porque o veículo está destruído, não avança, logo, é uma viagem sem direção, nem caminho. Esse autocarro destruído representa a casa do povo moçambicano que sofre a guerra e é esse passageiro sem destino, sem viagem, que sente que "o melhor da vida é o que não há-de vir" (Couto, 2013: 153).

O único valor é sobreviver, mas Muidinga, quando finge ser Kindzu, quer saber da felicidade, procura a bondade, a qual acaba por encontrar em Tuahir personificando Taímo, este explica que só o pode ensinar a brincar, a ficar sempre criança (Couto, 2013: 156-157). Tuahir alimenta a esperança de Muidinga, reinventando a realidade, fingindo uma viagem cuja estrada é o meio de transporte, explicando que a estrada, afinal, não estava morta, a estrada anda e eles viajam nela como se de um carrossel se tratasse. Todos os acontecimentos são ali perto: "Não somos nós que estamos a andar. É a estrada. [...] Era o país que desfilava por ali, sonhambulante. Siqueleto esvaindo, Nhamataca fazendo rios, as velhas caçando gafanhotos [...] Nesse machimbombo parado nós não paramos de viajar" (Couto, 2013: 138).

\subsection{Brincriação}

Muidinga, não podendo recordar, deseja imaginar: "Mas, tio é só imaginar. É um sonho que tenho..." (Couto, 2013: 40). A brincriação de fingir serem as pessoas dos Cadernos traz consolo a ambos por se sentirem pai e filho. Neste mundo de "ilusão", Muidinga sente-se protegido: "Seu pai estava ali, grande, sem mentira. Pela primeira vez alguém lhe dava abrigo. O mundo se estreava, já não havia escuro, não havia frio [...] Muidinga receia que o tio deseje quebrar aquele fingimento [...] Antes de adormecer o miúdo passa a mão por aquelas folhas, em cúmplice afago" (Couto, 2013: 157). O mundo da fantasia das crianças, das histórias, ouvidas ou escritas, a imaginação, a ilusão, são a única forma de encontrar a bondade e a felicidade para sobreviver à dura realidade em que vivem. No fundo, Tuahir é o salvador de Muidinga desde que decide ficar com o miúdo em vez de deixar que o enterrem vivo, assim, ele surge quase de um jeito maternal, benevolente e não deixa que esta criança se contamine da desesperança, mutuamente, vão alimentando a imaginação um ao outro como forma de sobrevivência, "o único valor, nos atuais dias" (Couto, 2013: 156).

\subsection{Entretempo}

A leitura marca o compasso da narrativa, pois temos o plano da narrativa de Miudinga e Tuahir que é intercalado com o plano da narrativa que corresponde à leitura noturna dos Cadernos de Kindzu. É como se a narrativa se estruturasse em ciclos diários, um capítulo com as experiências diárias do 
velho e da criança seguido de um capítulo com o momento noturno da leitura da criança ao velho, em que o descanso noturno é preenchido pela fantasia oferecida pela leitura, um mundo imaginário como um sonho que serve de descanso, de intervalo da realidade, é um momento em que tudo é possível, em que não se respira tristeza, porque se está absorto na imaginação, nas histórias do passado, dos antepassados, da moçambicanidade:

Os cadernos de Kindzu são uma fonte inesgotável de sonho e de alegria para Tuahir e Muidinga, pobres desgraçados que se encontram no interior de um ônibus incendiado para tentar escapar do inferno da guerra. Os dois personagens representam o povo moçambicano que não abandona seus sonhos e suas tradições (Oliveira, 2009: 110).

A leitura assume "uma função evasiva, no tempo e no espaço, que induz ao refúgio na nostalgia do passado ou na utopia do sonho (o não realizável) e no exotismo da paisagem natural e humana" (Paz, 2004: 130), que permite o descanso das almas das duas personagens que tentam sobreviver à guerra civil do seu país. O leitor e o ouvinte penetram nos mundos possíveis ficcionais de tal forma que o tornam real através do fingimento. A leitura apela ao fluir do imaginário, há o alargamento das vivências através do mesmo, dá-se a construção da cosmovisão ou concepção do mundo e a mundividência do leitor amplia-se: "No dia seguinte à leitura, seus olhos desembocam em outras visões" (Couto, 2013: 101).

A leitura serve para apaziguar a tristeza: "Você me vai ler mais desses escritos. [...] Problema é deixar este escuro entrar na cabeça da gente. Não podemos dançar nem rir. Então vamos para dentro desses cadernos. Lá podemos cantar, divertir" (Couto, 2013: 127). Por um lado, a leitura é um passatempo que os distrái. Muidinga e Tuahir não devem divertir-se para não fazerem barulho e serem descobertos pelos fazedores da guerra. Por isso, apesar de que "Rindo as alegrias acontecem", ambos param de rir para não chamarem a atenção e ficam "a respirar tristezas" (Couto, 2013: 126). Por outro lado, a leitura é um complemento da memória da criança que, curiosamente, esqueceu tudo do seu passado, exceto ler. Ler é o que sabe, aquilo que lhe resta da vida que teve: "Meus olhos se lembram das leituras, meus dedos não esqueceram as letras. Mas eu não sei lembrar nada do meu passado" (Couto, 2013: 126). Tuahir é o responsável pela falta de recordações, a memória é uma grande carga para ele e, provavelmente, também para uma criança que vive a guerra e a querem enterrar viva. Por esta razão, leva-a a um feiticeiro para eliminar a sua memória, "não ter lembranças deste tempo que passou. Ainda tiveste sorte (...) Pudeste esquecer tudo. Enquanto eu não, carrego esse peso" (Couto, 2013: 126). Não obstante, o feiticeiro não apaga tudo, deixa a capacidade de ler intacta, assim, a porta para a imaginação, a fantasia e o sonho é deixada aberta, o que alivia a realidade e o ajudará a (re)construir a sua identidade, preenchendo assim as páginas do seu passado: "os escritos de Kindzu traziam ao jovem uma memória emprestada" (Couto, 2013: 126). Numa narrativa em que as histórias das personagens são como as ondas, não cessam nunca, "as estórias se seguiam, se repetiam, trocavam e multiplicavam" (Couto, 2013: 94), Muidinga não tem história nenhuma. Assim sendo, "O tempo ele o queria apenas para mergulhar nas misteriosas folhas" (Couto, 2013: 35), criando uma memória, mesmo que de outrém, que lhe permite recriá-la.

A leitura é o entretempo, um período de tempo intermédio, em que "Acendo a estória, me apago a mim" (Couto, 2013: 15) como se de um sonho se tratasse, pois a guerra não permite viver. Kindzu escreve histórias que ouviu, para além de escrever a sua própria história, histórias que Miudinga lê para o seu ouvidor, Tuahir, que, por sua vez, também será estorinhador, pois contará histórias a Muidinga. Ambos ouviram as histórias que lhes contam as personagens que se vão deparando no seu dia-a-dia, Siqueleto, Nhamataca e, por último, o pastor. Numa tradição oral e, ao mesmo tempo, pela escrita, transmite-se a tradição, o jeito de um povo, as crenças, a memória, em suma, a moçambicanidade e abre-se um mundo de fantasia onde o velho Tuahir quer ser embalado da vida para a morte: "se solta do colo da terra, já livre, navegável. Começa então a viagem de Tuahir para um mar cheio de infinitas fantasias. Nas ondas estão escritas mil estórias, dessas de embalar as crianças do inteiro mundo (Couto, 2013: 196). 


\section{CONCluSÃo}

Muidinga e Tuahir fogem à tristeza com a leitura dos Cadernos de Kindzu, lidos como uma história de encantar, em que a realidade é substituída pela fantasia. É o momento em que se abre um novo mundo, o da imaginação, onde ainda cabe a vontade de viver. Apesar das memórias terríveis que são narradas, há um gesto pueril no tom da narrativa. Kindzu, farto da guerra, como um verdadeiro herói, parte da sua terra sozinho corajosamente, pois decide ser naparama, um guerreiro de justiça, que luta para terminar com o sofrimento. Ainda que invadido pelo medo, vivendo peripécias terríveis, não cessa em encontrar os naparamas para se juntar à sua luta.

O fim da narrativa dos Cadernos termina com um sonho de Kindzu. Ele transforma-se, finalmente, em naparama e encontra o seu irmão desaparecido, Junhito, ou Vinticinco de Junho, cujo nome faz alusão ao dia da independência de Moçambique. Simbolicamente, é como se essa independência fosse feita prisioneira pelo seu próprio povo, se transformasse no animal da guerra e acabasse por desaparecer sem deixar rasto, tal como sucede a Junhito, que fechado no galinheiro pela sua família, se transforma em animal e desaparece. Contudo, o regresso de Vinticinco de Junho no final do romance, tornando-se pessoa novamente no sonho de Kindzu, faz prever a (re)união da família, o regresso da infância e, com ela, o sonho, o final da guerra civil para a tão almejada independência brilhar.

Para além disso, a voz do defunto pai contra o seu abandono da aldeia, o que contrariava a tradição ancestral, e prevendo o mal, deixa de atormentar Kindzu, que encontra a estrada, e com ela, os seus cadernos e um menino. Gaspar? Muidinga? A criança que representa Moçambique, um país novo, uma identidade em construção, em que coexistem diferentes raças e culturas, sendo a diversidade o que constitui a identidade do país, bem como a da criança. Gaspar, o filho de Farida, e Muidinga, o órfão de Tuahir, isto é, a personagem das histórias dos Cadernos e o miúdo que lê essas histórias são um só. A ficção e a realidade encontram-se através do sonho da leitura, compondo um todo.

Por último, a cena final das folhas dos Cadernos a voar não é a destruição da escrita, é o semear dos sonhos nascidos daquelas histórias escritas. Isto para que nasçam mais sonhos, vividos pelo fantasiar das histórias. Escrever ou ler histórias é uma forma de evasão da realidade, de poder sonhar, fantasiar, criar uma realidade desejada, um sonho, uma esperança. Terra Sonâmbula é um romance composto por sucessivas histórias, que vão sendo lidas em voz alta por Muidinga, demonstrando a tradição oral e a sua importância. A escrita, tal como a leitura, abre as portas ao espaço do imaginário, da fantasia, e é para lá que os olhos de Muidinga mais se abrem: "O miúdo lê em voz alta. Seus olhos se abrem mais que a voz que, lenta e cuidadosa, vai decifrando as letras. [...] a estrada escuta a estória que desponta dos cadernos" (Couto, 2013: 14), até a estrada morta quer sonhar.

Em suma, a leitura é um remédio para a dor, pois a escrita traz sonhos, dá fruto. Siqueleto morre quando a escrita concebe uma árvore, cujo fruto são homens, pelo que a aldeia poderá ser replantada, reabitada. Também devido à escrita, as páginas dos Cadernos serão transformadas em sementes, neste caso, de histórias. Portanto, inumeráveis histórias poderão ser contadas, consentindo a recriação de um mundo imaginário em que conviva a inocência mais pura com a esperança e os sonhos. Deste modo, Kindzu morre semeando lembranças com as páginas de terra, sendo que a terra onde caem as folhas é a de Muidinga e essa tem um perfume doce devido à chuva que, reza a crença, é um bom presságio. Será uma terra fértil, pronta para que nasça a nova identidade e mais histórias, as quais criam sonhos. A escrita não morre, transforma-se em cada leitura, por conseguinte, os Cadernos de Kindzu semearão muitas outras histórias. As histórias unem a tradição oral e a escrita; o ancestral e o moderno; o escritor, o contador e o ouvidor; o passado, o presente e o futuro para construir uma nova realidade, uma nova identidade, a moçambicanidade da terra através de um olhar infantil e inocente repleto de esperança. 


\section{BIBLIOGRAFIA}

AAVV. «Fogo», Dicionário de Símbolos - Significados e Simbologias, 7Graus Ltd., https://www.dicionariodesimbolos.com.br/fogo/. (Consulta: 30/09/2021)

AAVV. «Guerra Civil Moçambicana», Infopédia da Porto Editora https://www.infopedia.pt/\$guerra-civil-mocambicana. (Consulta: 30/09/2021)

AAVV. «História de Moçambique: Penetração colonial», Portal do Governo, https://www.portaldogoverno.gov.mz/por/Mocambique/Historia-de-Mocambique/PenetracaoColonial. (Consulta: 30/09/2021)

AAVV. (2003) La Biblia, Barcelona, Herder.

Barthes, Roland (2001) O Prazer do Texto, colecção signos, Porto, edições 70.

Cantarela, Antonio Geraldo (2012) «A voz reinventada da tradição: ritos iniciáticos na obra de Mia Couto», HORIZONTE - Revista De Estudos De Teologia E Ciências Da Religião, 10, 25, 136156.

DOI: $10.5752 / \mathrm{P} .2175-5841.2012 \mathrm{v} 10 \mathrm{n} 25 \mathrm{p} 136$

Coimbra de Matos, Ana Catarina (2021) «Mia Couto y Vergílio Ferreira: Dos yos entre la realidad y la imaginación, o sueño», in Bárbara Fraticelli (ed.), Voces Africanas - Raza, Identidad, Género, Madrid, Sial - Casa de África, pp.133-151.

Costa, F. L. da e Godoy, M. E. B. de (2019) «A Terra Sonâmbula, de Mia Couto: memórias míticas e metáforas de Guerra», Revista (Entre Parênteses), 7, 2.

DOI: $10.32988 /$ rep.v2i7.760

Couto, Mia (2013): Terra Sonâmbula. Alfragide, Leya, SA.

Duarte, Andréa Ellen Aráujo e Job, Sandra Maria (2014) A literatura do exílio: Kindzu e Muidinga "a esperança nas páginas de terra", in ANAIS - I Colóquio de Letras da FALE/CUMB, Universidade Federal do Pará. ISSN 2358-1131 https://www.coloquiodeletras.ufpa.br/icoloquio-de-letras/anais-i/.

Ferreira, Ana Maria Teixeira Soares (2007) Traduzindo Mundos: Os mortos na narrativa de Mia Couto (Tese de doutoramento), Aveiro, Universidade de Aveiro. https://ria.ua.pt/handle/10773/2869

Garuba, Harry (2003) «Explorations in Animist Materialism: Notes on Reading/Writing African Literature, Culture, and Society», Public Culture 15(2), 261-286. https://www.researchgate.net/publication/31352130_Explorations_in_Animist_Materialism_No tes_on_ReadingWriting_African_Literature_Culture_and_Society.

DOI: $10.1215 / 08992363-15-2-261$.

Levécot, Agnès (2011) «Memórias do por-vir em prol duma possível identidade moçambicana: Terra Sonâmbula e o Último Voo do Flamingo de Mia Couto», Itinerarios - Revista de estudios 
Remédio da leitura em Terra sonâmbula

lingüísticos, literarios, $\quad$ históricos y antropológicos $\quad 14, \quad 135-151$. http://itinerarios.uw.edu.pl/memorias-do-por-vir-em-prol-duma-possivel-identidademocambicana-terra-sonambula-e-o-ultimo-voo-do-flamingo-de-mia-couto

Oliveira, Ana Maria Abrahão dos Santos (2009) «As impermanências da paisagem em Terra Sonâmbula», ABRIL - Revista do Núcleo de Estudos de Literatura Portuguesa e Africana da UFF, 2(2), 102-112. https://periodicos.uff.br/revistaabril/issue/view/1607.

DOI: 10.22409/abriluff.v2i2.29824.

Paradiso, Silvio Ruiz (2015) «Religiosidade na literatura africana: a estética do realismo animista», Revista Estação Literária 13 , 268-281. https://www.uel.br/revistas/uel/index.php/estacaoliteraria/article/view/27067

Paz, Olegário e Moniz, António (2004) Dicionário breve de termos literários, Lisboa, Editorial Presença.

Pereira, R. M. (2016) «Recortar, dividir, segmentar: saberes coloniales y su extensión poscolonial en Mozambique», Revista de Antropología Social 25(2), 341-360.

DOI: 10.5209/RASO.53976

Pessoa, Fernando (2017) Livro do Desassossego, Lisboa, Assírio \& Alvim.

Reis, Carlos e Lopes, Ana Cristina M. (2000) Dicionário de narratologia, Coimbra, Almedina. 